\title{
Review \\ Biodegradable Solvents: A Promising Tool to Recover Proteins from Microalgae
}

\author{
David Moldes ${ }^{1,2} \mathbb{C}^{-}$, Elena M. Rojo ${ }^{1,3}{ }^{(D}$, Silvia Bolado ${ }^{1,3}$, Pedro A. García-Encina ${ }^{1,3, *}$ \\ and Bibiana Comesaña-Gándara 1,3 (B)
}

1 Institute of Sustainable Processes, University of Valladolid, Dr. Mergelina s/n, 47011 Valladolid, Spain; david.moldes@uva.es (D.M.); elenamaria.rojo@uva.es (E.M.R.); silvia.bolado@uva.es (S.B.); bibiana.comesana@uva.es (B.C.-G.)

2 Department of Analytical Chemistry, Faculty of Sciences, Campus Miguel Delibes, University of Valladolid, Paseo de Belén 7, 47011 Valladolid, Spain

3 Department of Chemical Engineering and Environmental Technology, School of Industrial Engineering, University of Valladolid, Dr. Mergelina s/n, 47011 Valladolid, Spain

* Correspondence: pedroantonio.garcia@uva.es

check for updates

Citation: Moldes, D.; Rojo, E.M.;

Bolado, S.; García-Encina, P.A.;

Comesaña-Gándara, B.

Biodegradable Solvents: A Promising

Tool to Recover Proteins from

Microalgae. Appl. Sci. 2022, 12, 2391.

https://doi.org/10.3390/

app12052391

Academic Editor: Carlos Rico

de la Hera

Received: 28 January 2022

Accepted: 23 February 2022

Published: 25 February 2022

Publisher's Note: MDPI stays neutral with regard to jurisdictional claims in published maps and institutional affiliations.

Copyright: (c) 2022 by the authors. Licensee MDPI, Basel, Switzerland. This article is an open access article distributed under the terms and conditions of the Creative Commons Attribution (CC BY) license (https:// creativecommons.org/licenses/by/ $4.0 /)$.

\begin{abstract}
The world will face a significant protein demand in the next few decades, and due to the environmental concerns linked to animal protein, new sustainable protein sources must be found. In this regard, microalgae stand as an outstanding high-quality protein source. However, different steps are needed to separate the proteins from the microalgae biomass and other biocompounds. The protein recovery from the disrupted biomass is usually the bottleneck of the process, and it typically employs organic solvents or harsh conditions, which are both detrimental to protein stability and planet health. Different techniques and methods are applied for protein recovery from various matrices, such as precipitation, filtration, chromatography, electrophoresis, and solvent extraction. Those methods will be reviewed in this work, discussing their advantages, drawbacks, and applicability to the microalgae biorefinery process. Special attention will be paid to solvent extraction performed with ionic liquids (ILs) and deep eutectic solvents (DESs), which stand as promising solvents to perform efficient protein separations with reduced environmental costs compared to classical alternatives. Finally, several solvent recovery options will be analyzed to reuse the solvent employed and isolate the proteins from the solvent phase.
\end{abstract}

Keywords: biodegradable solvents; cell disruption; deep eutectic solvents; extraction with solvents; ionic liquids; microalgae biorefinery; protein recovery; protein release; solvent recovery

\section{Introduction}

Proteins are one of the three essential macronutrients in the diet and the most important to prevent malnutrition and hunger [1]. According to the United Nations, the global population will increase to 9.5 billion people by 2050 [2]; as a result, the demand for food, and therefore also for protein, will rise [3]. There are two primary protein sources of similar nutritional quality: animal (which includes meat, fish, eggs, and dairy products) and plant (legumes, and to a lesser extent, seeds, and nuts). However, animal protein is known for its high environmental and climate impact, not only for the emissions related to their production but also due to the arable land used for the intensive crop production for feed and a large amount of water required (for both feed and animals) [4]. Thus, it is necessary to find sustainable plant-based sources and production processes to meet future protein requirements without damaging the planet and human health [5]. One of the most promising alternative feedstocks are microalgae, which are photosynthetic organisms mainly composed of proteins, carbohydrates, and lipids [6,7]. Microalgae use solar energy to store carbon from $\mathrm{CO}_{2}$ conversion, and they also uptake nutrients from the culture medium for their growth [8]. This type of biomass has several advantages over 
others, including superior photosynthetic efficiencies and biomass production potentials than terrestrial crops, growth over a wide range of $\mathrm{pH}$ and temperature, capacity to uptake nutrients from different types of sources, such as wastewater, and most of them have a short generation cycle [9].

The content of proteins, carbohydrates, lipids, and other microalgae biocompounds can be utilized as feedstock for various bioproducts applying biorefinery processes [10]. Nevertheless, the current approaches are still not profitable and have some challenges to be addressed [11]. The price of microalgae cultivation is a notable drawback of microalgaebased biorefineries, but the use of low-cost culture medium as wastewater could contribute to achieve economically sustainable processes. As a result, the microalgae biorefinery approach can be integrated within the circular bioeconomy, whose main goals are to reduce, reuse, and recycle raw materials [11]. Additionally, biomass's integral and fractional valorization could maximize the process benefits by taking advantage of waste streams, promoting this circular bioeconomy [7].

The characteristics and composition of microalgae depend on the species and the environmental and operational conditions during cultivation [12]. However, in most cases, the main constituents of microalgae biomass are proteins, ranging from 30 to $70 \%$ mass percentage in dry weight [13], achieving the higher protein concentrations in microalgae grown in stressful environments such as wastewater. Due to the proteins' high added value and lability, it is reasonable to first recover the protein fraction in the process of fractional valorization of this biomass. The major issue with protein recovery is related to where the proteins are found in the cell. Typically, these biomolecules are inside a very recalcitrant cell wall that is difficult to break and whose thickness and chemical composition depend on various factors such as growth stage, cellular form, and environmental conditions [14]. Hence, the first step of a biorefinery process to recover biomolecules from microalgae is the cell wall disruption by physical, chemical, or biological methods to extract intracellular molecules by different solvents [15]. The use of organic solvents is a well-known technique for the extraction and separation of microalgae biomolecules, but some of them are toxic and not aligned with environmental and human health concerns [16]. Thus, alternative solvents have recently begun to be studied, such as ionic liquids (ILs) and deep eutectic solvents (DESs), with lower environmental impact than conventional solvents and promising applications in microalgae processing [17].

\section{Microalgae Biorefinery: Biomass Treatment}

According to Chew et al., the biorefinery is a "process to obtain biofuels, energy and high-value products through biomass transformation and process equipment" [18]. In the case of microalgal biorefinery, microalgae biomass is used as feedstock. Different steps are involved in the process, including cultivation, harvesting, cell disruption, component recovery, and final product purification [19]. The development of these new industries is faced with critical challenges; as an example, industrial photobioreactors for cultivation in synthetic media have high costs and reach low biomass concentrations. At the same time, current downstream processes are designed for a single main product, and the rest of the microalgae biomass is frequently "waste" that is not useful [11]. Because of all this, it is necessary to develop more efficient technologies to achieve a sustainable process for microalgal cultivation, but also to profit and valorize all the components of this microalgal biomass, establishing a fractional biorefinery process. This sequential valorization main concern is the release of different fractions without damaging the other fractions to attain an integral recovery of the biomass components [18].

The first step for the microalgae valorization is the cell disruption (Figure 1), which is a critical process for obtaining the desired biocomponents from intracellular contents [20]. Microalgae cells present a high resistance to intracellular extraction, usually attributed to their rigid cell walls [21]. This cell wall consists of a microfibrillar network composed of diverse polysaccharides, proteins (mainly glycoproteins), and a biopolymer called algaenan, which is very difficult to degrade [14]. This cell disruption can be achieved by several 
processes, which can be classified into physical (e.g., bead milling, high-pressure homogenization, microwave irradiation, ultrasonication, pulse electric field), chemical (e.g., acid, alkali, and thermal hydrolysis) and biological methods (e.g., enzymatic hydrolysis) [16] However, most of these techniques require harsh conditions (such as chemical methods), which allow obtaining high release efficiencies but at the expense of degrading the released bioproducts, resulting in low recovery yields. Thus, the use of mild cell disruption will maintain the biomolecule's activity and functionality to provide high-quality products [20]. Moreover, in order to take advantage of all the algal biomass and achieve a sustainable process, cell wall components (including some types of proteins) may themselves also be target molecules within the biorefinery process [15].
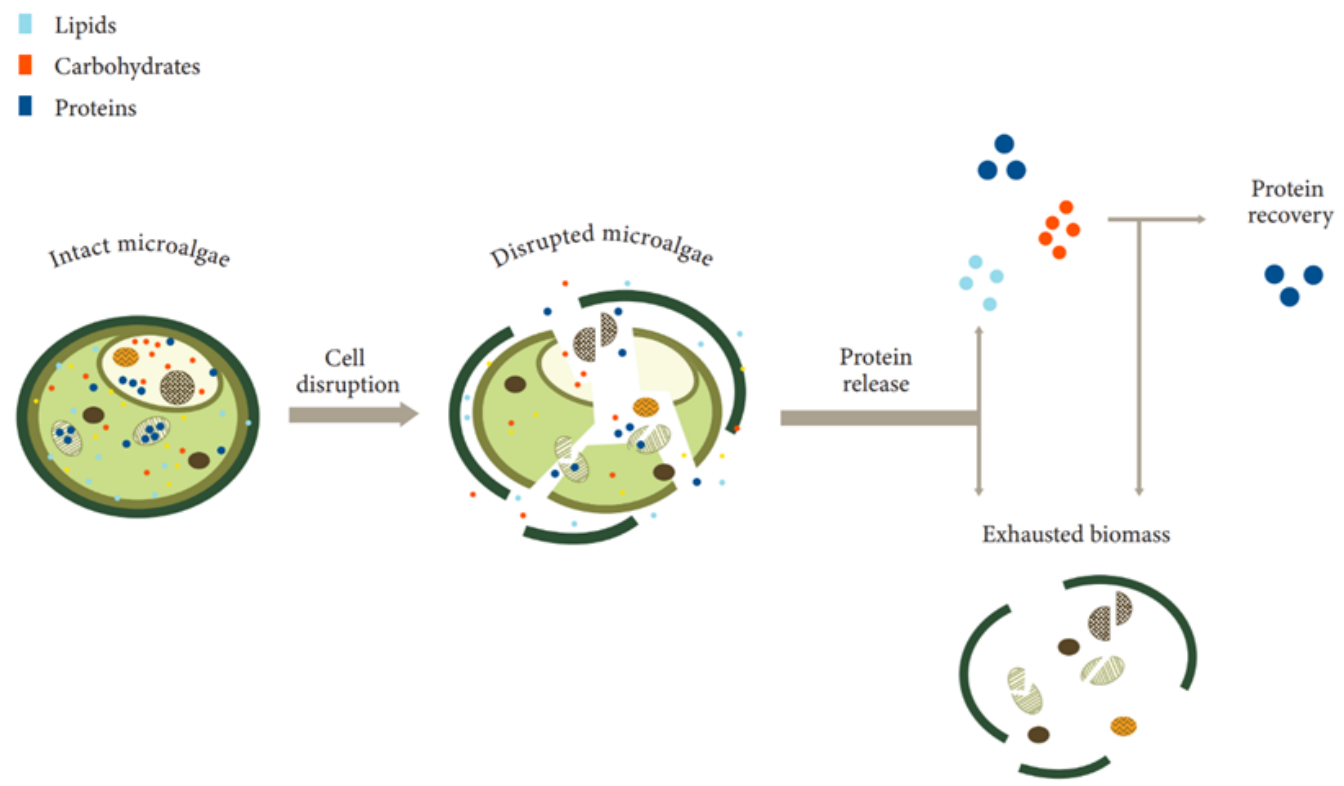

Figure 1. Scheme of proteins obtaining from biomass. Adapted from [22].

Once the cellular disruption occurs (Figure 1), the biomolecules contained inside the cell are released (proteins, carbohydrates, or lipids), usually employing an extraction solvent. Those soluble biomolecules will be in a liquid phase, whose composition will depend on the cell disruption method and extraction conditions. Therefore, a recovery step is needed to isolate the required product from the other released compounds [16].

In the case of protein recovery, there are many possible techniques, including chemical precipitation, electrophoresis, membrane filtration, chromatography, or solvent extraction [23]. Although some of these methods provide good separation results, they have essential disadvantages such as low resolution, use of toxic solvents, presence of plenty of impurities, time-consuming process, and the use of harsh conditions such as high temperatures or energy consumption, which may lead to protein denaturation [23,24]. Furthermore, a single methodology usually cannot achieve the desired purification effect. Among all these alternatives, solvent-extraction stands as an attractive technique because it is well known, efficient, and easily scalable. Nonetheless, the use of traditional toxic organic solvents can lead to changes in the stereochemistry and degradation of the released proteins [12]. Thus, there is a high demand for suitable non-toxic solvents that do not damage proteins. Two new types of solvents have been developed recently to substitute conventional organic solvents, which are in the category of biodegradable solvents: ionic liquids (ILs) and deep eutectic solvents (DESs) [25]. Biodegradable solvents are an interesting replacement for classical solvents, as they have lower toxicity and are a more environmentally friendly alternative. In this regard, DESs are considered excellent substitutes to address these bottlenecks [26], since they are instrumental as a suitable solvent for the release and purification of several proteins without altering their native structure [27]. In the following 
sections, different approaches for protein recovery will be considered, particularly from microalgae biomass, emphasizing biodegradable solvents.

\section{Protein Recovery}

Once the microalgal biomass has been adequately treated, obtaining proteins selectively from the liquid phase with all the released compounds requires the use of recovery approaches. The recovery stands as one of the bottlenecks of the process [28,29], as the purity levels of the proteins obtained will determine their subsequent applications [23]. Generally, using a single recovery step is not enough to isolate proteins of enough purity. Thus, the current trend is to follow a multiple-step approach [19]. The process becomes complicated because of the hydrophilic nature of proteins, which makes them prone to denaturation, precipitation, and degradation. Proteins are fragile molecules, so mild operation conditions are required to preserve their native structure and biological activity. A brief description of the most used conventional separation techniques, along with new emerging alternatives such as biodegradable solvents, which are up-and-coming tools to perform efficient protein purification [22], will be related in this section, with a focus on their physicochemical basis, pros, and cons. Other techniques such as molecular imprinting [30], magnetic separation [31], or electrostatic separation [32] are attracting researchers' attention, but they are still in a very incipient state.

\subsection{Precipitation Methods}

Precipitation is a process in which a solid is obtained from a solution, in the case of proteins, by adding a precipitation agent. Precipitation is a suitable method for crude protein recovery, and it preserves the structural activity of the proteins [33,34], but it is inefficient for further purification stages as it does not provide high recovery yields and efficiencies [23]. Depending on the precipitation agent used, three distinct approaches have been tried for microalgae protein recovery: (i) isoelectric point precipitation, which deals with $\mathrm{pH}$ changes; the compounds usually employed are $\mathrm{NaOH}$ and $\mathrm{HCl}$ [35]; (ii) salting-out, consisting of using a high concentration of salt solutions such as $\mathrm{NaCl}$ or $\mathrm{K}_{2} \mathrm{HPO}_{4}$ [36], and (iii) organic solvent precipitation, for which classical organic solvents such trichloroacetic acid or mixtures of ethanol and acetone, are commonly used [37]. This latter approach affords a larger protein recovery yield than isoelectric point precipitation or salting-out; however, classical organic solvents are not advisable due to their environmental concerns and the complexity of solvent recovery.

\subsection{Membrane Separations}

Membranes are boundaries between two phases. They have been widely used in the separation field, achieving high selectivity. Non-solvent or harsh conditions are involved, and the purification can be carried out at low temperatures, preventing protein degradation [38,39]. However, classical filtration usually is a slow process. To solve this issue, tangential and cross-flow processes of microfiltration (MF) and ultrafiltration (UF) have been developed. MF membranes are good at separating components ranging from 10.0 to $0.1 \mu \mathrm{m}$ [40], even though modest recovery yields are usually achieved after filtration [41]. On the other hand, UF employs membranes with a pore size of $0.1-0.01 \mu \mathrm{m}$, requiring slightly higher pressures than $\mathrm{MF}$ (0.5-5 bar versus $0.1-2$ bar required for $\mathrm{MF}$ ) or the use of centrifugal force [40]. There are some handicaps for the implementation of membranes to industry, and fouling is probably the most troublesome point, as it reduces membrane permeability, decreasing the filtration performance. That is one of the reasons why tangential filtration of cross-flow filtration has gained importance in recent years $[42,43]$. Only a couple of studies have been found applying membrane filtration for microalgae protein recovery [44,45].

Despite MF and UF consisting of semipermeable membranes, the driving force in both cases is the external pressure applied. In opposition, dialysis is a separation method based on the concentration gradient established between the phases [23]. Dialysis can aid 
in removing ionic species from the protein fractions obtained [46] as part of a combination of protein purification methods.

\subsection{Electrophoresis and Chromatographic Techniques}

Electrophoresis separates analytes according to their mobility through an aqueous buffer in response to an electric field. The most common mode for protein purification is capillary electrophoresis [16]. Electrophoresis is an excellent technique to identify and quantify amino acids [47], but it is scarcely used for industrial protein purification because of its long operational times and low sample intake.

Chromatographic methods, in turn, allow the separation of closely related molecules in complex mixtures [48]. Chromatographic techniques used for protein purification are gel permeation, ion-exchange, affinity, and hydrophobic interaction chromatography $[49,50]$. Sometimes, protein purification might require the combined use of several chromatographic techniques. For example, the use of a first stage in which ion-exchange chromatography separates protein fractions according to their charge, and then a gel permeation stage to obtain proteins with similar charge and size, resulting in the so-called two-dimensional approach, used for proteomic separation. Although chromatography is often oriented to quantitative analysis, some operational modes can be applied to purify molecule fractions, known as preparative chromatography [51]. Nevertheless, chromatography is an expensive technique and not easy to scale up [52]. In addition, it demands high amounts of organic mobile phases, which is not environmentally sustainable [53]. Therefore, chromatographic techniques are not a good alternative for microalgae proteins at the industrial level [23].

\subsection{Solvent Extraction}

As mentioned above, solvents can be used to release the proteins from inside the biomass cell, but they can also be employed to selectively obtain proteins from the released compounds through conventional liquid-liquid extraction (LLE). This separation technique consists of the analyte's migration to the extracting phase, relying on the different affinity for the medium (measured by the distribution constant, $K_{D}$ ) and the concentration gradient [54]. This section will discuss classical and new emerging solvents for protein LLE, along with innovative solution combination strategies.

Commonly employed solvents for protein recovery are hydrocarbons, alkalis, acetone, alcohols, and chloroalkanes [55]. Even though these solvents are low-cost and have good solubility capacities [56], they also present important drawbacks such as long operational times, high solvents and energy consumption, and the high odds of separated proteins damage [57]. Furthermore, most of them are volatile organic compounds (VOCs) derived from non-renewable sources such as petroleum, being both detrimental to human health (as the product obtained might introduce pollutants) and the earth's well-being $[56,58]$. The use exclusively of classical solvents to obtain proteins from microalgae is not common. However, several studies reported their use in combination with greener options such as aqueous two-phase systems, in which the organic solvent volume is significantly reduced [59].

Due to the drawbacks of classical solvents, alternative strategies are needed to achieve more sustainable processes, with reduced energy consumption and lower presence of hazardous substances [60]. One approach to accomplish these goals consists of replacing classical for green solvents, which must be cheap, non-toxic, safe, stable, biodegradable, renewable, and atom economic in their synthesis; however, telling which solvents are green is still a controversial issue [61]. Moreover, most typical green solvents are not preferred for protein recovery because proteins are not very soluble in water [56] nor supercritical fluids such as $\mathrm{CO}_{2}$ [62]. Thus, the aim is to find greener solvent options for LLE, and one class of solvents that have shown promising results in the recovery of bioactive compounds are the so-called biodegradable solvents, which are not necessarily fully green (although every green solvent must be biodegradable). The advantage is that defining what a biodegradable solvent is can be quantified in a rigorous manner $[63,64]$. These solvents can be combined with innovative assisted technologies such as microwave, or ultrasound, to achieve an 
optimum purification process [55,62]. This is the case for ionic liquids (ILs) and deep eutectic solvents (DESs), whose advantages and applications will be examined in Section 4 .

Another possibility is to combine two different solutions to carry an LLE process, as applied in an aqueous two-phase system (ATPS), which can also be found in literature as aqueous biphasic system (ABS) [65]. As its name indicates, ATPS consists of two aqueous phases that are immiscible due to the repulsive behavior of their components $[66,67]$. Compared to classical single solvent extraction, ATPSs allow obtaining in one step proteins in high concentration, saving time and costs, as the equilibrium is rapidly reached [68]. One phase is usually formed by a water-soluble polymer solution or a hydrophilic organic solvent (such as alcohols or organic acids), while the other is generally a salt solution [69]. ATPSs allow mild operation conditions, reducing the chance of denaturation or loss of structural activity of the proteins [69]. Moreover, ATPSs enable continuous mode operation conditions, so they are easy to scale up, unlike other techniques, restricted to batch mode [65]. ATPS containing conventional organic solvents has proved potential for microalgae protein purification; for example, Phong et al. [59] prepared an ATPS formed by aqueous solutions of ammonium sulfate and 2-propanol; or Baskaran et al. [70], who, instead of the 2-propanol, used polyethylene glycol 600. Nevertheless, the interest is focused on ATPS based on green or biodegradable solvents, as they show the excellent properties of a typical ATPS using non-toxic components (or at least, less detrimental). The main drawback of these methodologies is the insufficient knowledge about the recovery from the phase in which the proteins are concentrated, and, in fact, this is still the subject of extensive research [23].

In summary, solvent extraction can be performed through single-solvent extraction and with an ATPS system. Substituting classical solvents with biodegradable solvents will ensure a greener process compared to the traditional approaches. In this regard, ILs and DESs emerged as suitable alternatives, as they enable more efficient and selective purifications, not damaging the structural activity of the proteins extracted and being more environmentally friendly than classical solvents.

\section{Biodegradable Solvents for Protein Extraction}

Biodegradable solvents are compounds able to be degraded in smaller chemical entities by biological organisms' actions and other factors such as temperature or light. The two types of biodegradable solvents more studied for biocompounds recovery, and in particular for proteins, are ILs and DESs, which are also known as "designer solvents" because their physicochemical properties can be tuned if needed for further improvements on the separation performance, achieving high protein recovery yields [71]. Most authors do not grant them the category of "green" because, despite their good biodegradability and environmental advantages, other requisites needed are not fulfilled, such as high stability under high temperature and low pressure, flammability, and potential toxicity [61]. In addition, other aspects related to solvent preparation must be examined, for example, the synthesis process of ILs employs organic solvents and demands high temperature and reaction times, not to mention the final purification step always required, so overall, the process could not be considered green [72]. Hence, it is advisable to refer to them as biodegradable solvents.

In this section, ILs and DESs for solvent protein extractions will be reviewed, detailing their characteristics, differences, strengths, weaknesses, application range, together with a revision of the current greenness state of both types of solvents. Finally, the solvent recovery options available will be evaluated.

\subsection{Ionic Liquids (ILs)}

ILs are liquid salt mixtures at room temperature [73]. This low melt temperature is a result of their low-charge density and low symmetry ions of the organic salts, along with ionic interactions, hydrogen bonds, and dipole-dipole intermolecular forces [74]. Generally, to obtain salts in the liquid state, very high temperatures are required to disrupt the strong 
ionic interactions. However, the strong electrostatic interactions of ILs lead to a lowering of the melting point below $100{ }^{\circ} \mathrm{C}$ [75]. Although there are many options for organic salts, cations are usually exclusively organic derivatives, while anions might have either organic or inorganic nature [76]. Because of their molecular structure, ILs possess outstanding physicochemical properties compared to organic solvents: low vapor pressure $(<1 \mathrm{~Pa})$, high conductivity, moderate thermal stability, and great extraction capacities for many organic and inorganic compounds [77]. They also have a wide electrochemical window, and valuable polarity properties, depending on the ions used [78]. Moreover, thanks to their physicochemical characteristics, some ILs (such as 1-tetradecyl-3-methylimidazolium bromide, or 1-ethoxyethanol-3-methylimidazolium chloride, etc.) have demonstrated promising results in guaranteeing the stability and activity of proteins, as shown in the review published by Patel et al. [79]. Nevertheless, details of the mechanism of action of how the IL interacts with proteins to extract them still need to be elucidated [72].

The first IL was synthesized in 1914 by Paul Walden, yet until 2007, they were not explicitly applied to extract biocompounds [76]. To synthesize an IL, diluted solutions of each ion must be prepared and mixed correctly. When the reaction ends (which usually takes up to $48 \mathrm{~h}$ and needs $25-100{ }^{\circ} \mathrm{C}$ ), the solid residue is removed and washed with an organic solvent. As stated by Xiao et al., ILs have been used extensively to extract natural products [80]. However, attention must be paid to the ion components chosen to maximize the analyte-solvent interactions, leading to a more efficient process [72].

Extraction of proteins from microalgae biomass can be carried out by single IL solvent extraction or through an ATPS system. Single IL extraction is usually aided with a complementary technique such as ultrasonication or microwave. Rodrigues et al. evaluated different ILs and their mixture for obtaining phycobiliproteins from Spirulina platensis [81]. The authors extracted the highest protein concentration using an equimolar mixture of 2-hydroxyethylammonium acetate and 2-hydroxyethylammonium formate using an ultrasonication bath $\left(25^{\circ} \mathrm{C}\right.$ and $\left.25 \mathrm{kHz}\right)$ and a solvent:biomass ratio of $7.93 \mathrm{~mL} \mathrm{~g}^{-1}$. The $\mathrm{pH}$ was fixed at 6.50 , and the extraction time was set to $30 \mathrm{~min}$. The protein recovered in a more significant amount was allophycocyanin, attaining values of $6.34 \mathrm{mg} \mathrm{g}^{-1}$, but also $5.95 \mathrm{mg} \mathrm{g}^{-1}$ of phycocyanin and $2.62 \mathrm{mg} \mathrm{g}^{-1}$ of phycoerythrin were recovered. As another example, Desai et al. also extracted proteins and astaxanthin by treating the liquid microalgae extract from Haematococcus pluvialis with the commercial trihexyl(tetradecyl)phosphonium bistriflamide ionic liquid and a microgel-stabilized emulsion. They reached an average extraction efficiency greater than $90 \%$ using a solvent:biomass ratio of 3:7, a microgel particle concentration of $1 \mathrm{~g} \mathrm{~L}^{-1}$, and mixing time of $120 \mathrm{~min}$; the proteins recovered preserved their native state after separation [82]. Similarly, Lee et al. employed an IL-buffer (cholinium 2-hydroxy-3-morpholinopropanesulfonate) at $\mathrm{pH}$ of 7.00 combined with ultrasonication $(400 \mathrm{~W} ; 24 \mathrm{kHz} ; 5 \mathrm{~s}$ on $/ 5 \mathrm{~s}$ off pulse mode) to obtain proteins from Chlorella vulgaris. Proteins were recovered in a single step operation (extraction from the cell and purification occurred simultaneously) with an almost complete recovery yield of $95.0 \pm 1.9 \%$ [83]. Instead of ultrasonication, Desai et al. applied bead milling as a cell disruption technique and managed to separate lipids of carbohydrates and proteins from Neochloris oleoabundans. They used a $40 \%$ solution of tributylmethylphosphonium methyl sulfate, a biomass concentration of $6.67 \mathrm{~g} \mathrm{~L}^{-1}$ at $45^{\circ} \mathrm{C}$ after $30 \mathrm{~min}$. After centrifugation, the lipids were obtained in the solvent phase (68\% recovery yield of total lipids). The proteins and carbohydrates remained in the microalgae biomass, which was subsequently mechanically disrupted, leading to an aqueous phase rich in those components, achieving $80 \%$ recovery yield for proteins and $77 \%$ for carbohydrates [84].

Concerning IL-based ATPS, there is more research when compared to single ILs extraction, as it combines the advantages of using ionic liquids with the benefits of following an ATPS approach: short extraction time, low viscosity, and options of recyclability [85]. The most common IL-based ATPS is composed of one ionic liquid and an aqueous polymer or salt solution [86-88]. For instance, Suarez Ruiz et al. studied the fractionation of several microalgal biomolecules: proteins, carbohydrates, lipids, and pigments, from Neochloris 
oleoabundans, grown in saline freshwater conditions [86]. After cell disruption, it was treated with three different ILs-ATPSs with a polymer-rich phase. A multistep fractionation process was implemented, and the system formed by PPG400-Ch DHp provided the best results, attaining an $82 \%$ of protein recovery in the IL phase, along with pigments $(98 \%)$ and carbohydrates $(93 \%)$, while lipids and starch were isolated from the interface, with recovery yields of 79 and $71 \%$, respectively. Then, they proposed a further purification step applying ultrafiltration, selectively obtaining $80 \%$ of proteins from sugars and $\mathrm{IL}$, allowing the recycling of the solvent. Rodrigues et al. also concluded that the electrostatic interaction between proteins and the IL might be the driving force of the separation process. Using salts instead of polymers $\left(\left[\mathrm{C} 8_{\text {mim }}\right] \mathrm{Cl}-\mathrm{K}_{3} \mathrm{PO}_{4}\right)$ to Isochrysis galbana, Santos et al. achieved a selective and efficient carbohydrate-protein separation, with $100 \%$ of proteins in the top phase, and $71 \%$ of carbohydrates in the bottom phase [87]. García et al. also employed an IL-salt ATPS, consisted of Iolilyte 221PG as IL, and potassium citrate tribasic monohydrate as salt, obtaining protein extracts with industrial relevance from crude microalgae Neochloris oleoabundans and Tetraselmis suecica applying mild conditions ( $\mathrm{pH}=7.0$ and room temperature) [88].

The number of published articles concerning ILs grew until 2016, when concerns about their toxicity surpassed their assumed benefits. Even though ILs do not pollute the air due to their low vapor pressure at room temperature, some of the ions used have displayed ecotoxicological effects, flammability, and have proved to be poorly biodegradable [89]. However, not all ILs are indeed equally harmful. Some choline-based ILs derived from biomaterials (Bio-ILs) have shown low toxicity and high stability [90], substituting the cation (typically pyridinium or imidazolium) by choline. Nonetheless, the appearance of Bio-ILs has not prevailed among scientist investigations [91,92]. Furthermore, synthesizing ILs is expensive compared to classical solvents [93], mainly due to the starting products, which are obtained from fossil fuels sources, making the process less green, as waste is created indirectly [94]. Other important aspects of any green extraction are the recovery of the value-added compounds (hindered by their low vapor pressures) and the capacity of the solvent to be recovered and reused. These issues remain a challenge, and there is a need for further research, as generally, studies focused only on measuring protein content on the IL and are not concerned about these aspects (more information in Section 4.3) [76]. These drawbacks prevent the widespread ILs in the industry and engender the need for alternative greener options.

\subsection{Deep Eutectic Solvents (DESs)}

To avoid the problems associated with ILs, scientists turned their interest into a newly emerging type of solvents, DESs, which was first described in 2003 by Abbott et al. [95]. DESs are liquid mixtures at room temperature, formed by the combination of two solids (or a solid and a liquid) in a specific molar ratio, for which the eutectic point temperature is below that of an ideal mixture, much lower than the compounds separately [96]. The liquid obtained shows exceptional physicochemical properties similar to ILs [97]. Generally, the eutectic point is found in a significant depression, around $150{ }^{\circ} \mathrm{C}$ lower than if the mixture had an ideal behavior [98], and it is thought to be caused by the charge delocalization produced between the molecules mixed [99].

Some authors consider DESs as a subclass of ILs. However, most agree that DESs are a different kind of solvent because they are not formed exclusively by ionic species (existing DESs with non-ionic compounds), and no chemical reaction is involved in their preparation $[17,62,98,100]$. DESs have two components: a hydrogen bond donor (HBD) or a metal halide and a hydrogen bond acceptor (HBA). The hydrogen bond interaction between those components forms the eutectic mixture [98]. The variety of those two groups is enormous, so it is estimated there could be around $10^{6}-10^{8}$ possible combinations to form DESs [101]. Depending on the chemical nature of the components, DESs are classified into five distinct types (Table 1) [102,103]. However, most of the research has focused on Type III: DESs consisting of a quaternary ammonium salt as HBA (usually choline chloride) 
and a suitable hydrogen bond donor such as alcohols, carboxylic acids, or amides [104]. This is because type III shows a stronger hydrogen bond interaction, which directly affects the physicochemical properties of DESs [105].

Table 1. General classification of DESs [102,103].

\begin{tabular}{ccc}
\hline Type & General Formula & Terms \\
\hline I-HBA and metal chloride & $\mathrm{Cat}^{+} \mathrm{X}^{-} \mathrm{z} \mathrm{MCl}$ & $\mathrm{M}=\mathrm{Zn}, \mathrm{Sn}, \mathrm{Fe}, \mathrm{Al}, \mathrm{Ga}, \mathrm{In}$ \\
$\mathrm{II}-\mathrm{HBA}$ and metal chloride hydrate & $\mathrm{Cat}^{+} \mathrm{X}^{-} \mathrm{z} \mathrm{MCl}_{\mathrm{n} \mathrm{H}} \mathrm{O}$ & $\mathrm{M}=\mathrm{Cr}, \mathrm{Co}, \mathrm{Cu}, \mathrm{Ni}, \mathrm{Fe}$ \\
III-HBA and HBD & $\mathrm{Cat}^{+} \mathrm{X}^{-} \mathrm{z} \mathrm{RZ}$ & $\mathrm{Z}=\mathrm{OH}, \mathrm{COOH}, \mathrm{CONH} 2$ \\
IV-Metal chloride and HBD & $\mathrm{MCl}_{\mathrm{n}}+\mathrm{RZ}=\mathrm{MCl}_{\mathrm{n}-1}{ }^{+} \mathrm{RZ}+\mathrm{MCl}_{\mathrm{n}+1}$ & $\mathrm{M}=\mathrm{Al}, \mathrm{Zn} ; \mathrm{Z}=\mathrm{OH}, \mathrm{CONH} \mathrm{O}_{2}$ \\
V-Molecular compounds & Non-ionic DESs & Molecular substances \\
\hline
\end{tabular}

$\mathrm{Cat}^{+}$: ammonium, phosphonium, or sulfonium cation. $\mathrm{X}^{-}$: Lewis base (generally, a halide). HBA: hydrogen bond acceptor. HBD: hydrogen bond donor. R: alkyl rest. z: stoichiometric coefficient.

As mentioned, DESs have similar physicochemical properties compared to ILs, since they present low volatility and vapor pressure (slightly larger than ILs), thermal stability, and tunable polarity, which allow solubilization of various molecules, including proteins [104]. The separation mechanism is meant to imply several forces such as hydrophilichydrophobic or electrostatic interactions, although it is thought that their excellent protein extraction capabilities are driven by the formation of protein-DES aggregates [24,106]. Contrary to ILs, DESs starting materials are cheap, easy to produce, and do not entail associated pollution (most are allowed for human consumption). DESs are also more biodegradable than ILs (>69.3\% in 28 days, according to Zhao et al. [107]), but the nature of the ions highly determines their biodegradability [72]. Moreover, DESs are considered mixtures rather than pure compounds [96], so there is no need for by-product removal as no chemical reaction has occurred (process with $100 \%$ of the atom economy, as opposed to ILs). Due to their outstanding properties, such as great biodegradability, comparable physicochemical properties of ILs, and small or no toxicity, DESs are applied in many fields such as electrochemistry, organic and inorganic chemistry. In addition, DESs are being used in separation strategies replacing the role of ILs, as they are considered a greener alternative [108].

However, as reported by Chen et al. [61], not only the greenness of ILs must be questioned. Some DESs should also be critically reevaluated, as they encompass some downsides such as hygroscopicity, toxicity, regenerability and renewability, and decomposition at high temperatures. To circumvent some of these problems, Choi et al. found that a DES-like liquid could be formed when mixing natural primary cellular metabolites such as choline, sugars, betaine, alcohols, organic acids, and amino acids [109]. Thus, using natural products to prepare DESs (natural deep eutectic solvents or NADESs) will ensure low or negligible environmental impact and toxicity, as these new solvents are biodegraded $>70 \%$ in 7 days [110], along with ubiquity and low cost [62]. A rigorous comparison of the key properties of ILs, DESs, and NADESs, has been recently performed by Mehariya et al., highlighting that NADESs are more eco-friendly and exhibit lower toxicity than DESs, which in turn are better in these and other aspects such as biodegradability, cost, and synthesis facility than ILs [111]. NADESs have proved to be an ideal extraction media since many macromolecules such as DNA, proteins, carbohydrates, and other small molecules are highly soluble in some of these solvents such as 1,2-propanediol-choline chloridewater, glucose-choline chloride-water, or lactic acid-glucose-water, as demonstrated by Dai et al. [112]. Analogous to ILs, the complete understanding of the underlying extraction mechanism is yet to be elucidated. Even though NADESs show numerous advantages and are considered capable of dissolving all sorts of biomolecules in living things [109], they also present some limitations, such as their high viscosity, which may prevent further industrial application. Nonetheless, this issue can be solved by increasing the operation temperature, or by adding water, which is preferred to maintain the structural activity of the proteins extracted [111]. 
Many works have proved the good performance of DESs to selectively extract proteins for several matrices, such as animal tissues or plant-derived sources like oilseeds [24,113-117]. For instance, Bai et al. achieved $>90 \%$ of extraction efficiency for collagen proteins from cod skin, with the corresponding purity of $93 \%$, using the single-DES formed by choline chloride and oxalic acid in optimum conditions [115]. Turning the attention to the research focused on matrices similar to microalgae biomass, it is worth mentioning Grudniewska and coworkers research, in which protein-rich extracts from rapeseed cake and evening primrose cake, residues derived from the oil industry were obtained using a choline chloride:glycerol DES, in 1:2 molar ratio. Once the proteins are in the DES phase, they can be precipitated using water as an anti-solvent, increasing the percentage of protein in the final extract up to $20 \%$ compared to the starting biomass [114]. However, most of the research is focused on DES-based ATPS, as it is usually the most efficient technique to recover and purify proteins due to the low interfacial tension of these systems. For instance, Li et al. developed a biphasic system based on a NADES containing betaine as HBA, urea as HBD, and water in a 1:2:1 molar ratio, reaching an extraction efficiency of $99.82 \%$ for BSA, and therefore showing ATPS are valuable tools for protein obtaining [117].

Regarding protein recovery from microalgae using DESs, only a couple of studies were found $[118,119]$. Firstly, Cicci et al. carried out three sets of experiments applying different pretreatments to study the extraction of proteins, lipids, carbohydrates, carotenoids and chlorophylls from Scenedesmus dimorphus (UTEX 1237) [118]. The NADES was prepared by combining 1,2-propanediol, choline chloride, and water in a 1:1:1 molar ratio. The experimental set-up consisted of putting in contact the solvent with the biomass and simultaneously applying different cell disruption methods (ball mill/ultrasonication/none). The highest protein extraction yield was achieved with the ultrasound-assisted experiments, attaining a $27 \%$. No further purification was performed to isolate the extracted proteins. Subsequently, Sed et al. conducted a study with the same microalgae, but using a new NADES (based on a mixture of octanoic and dodecanoic fatty acids) and a sequential two-stage extraction, consisting of a first extraction step using the solvent in its hydrophilic form (recovering the proteins), and then a second phase with the solvent in its hydrophobic mode, providing the solvent and other hydrophobic compounds. The protein extraction efficiency achieved was 100\% [119].

Hence, solvent extraction with DESs or ATPS-DES is a promising sustainable technique for protein recovery. However, there is still much scope to further investigate these methodologies for microalgae protein extraction and also for the purification of the proteins once they are extracted.

Table 2 compiles the protein recovery studies reviewed in this article, summarizing the IL or DES employed, the salt or polymer used (in case of following ATPS approach), the specific process conditions, and finally the protein yield addressed.

Table 2. Protein recovery from different microalgae with ILs, DESs, and ATPS shown in this review.

\begin{tabular}{|c|c|c|c|c|c|}
\hline $\begin{array}{l}\text { Microalgae } \\
\text { Strain }\end{array}$ & $\begin{array}{l}\text { DES/IL Used } \\
\text { (Molar Ratio) }\end{array}$ & $\begin{array}{c}\text { Salt/Polymer } \\
\text { Used (in Case } \\
\text { of ATPS) }\end{array}$ & $\begin{array}{l}\text { Extraction Method } \\
\text { and Conditions }\end{array}$ & Yield & Reference \\
\hline \multirow{5}{*}{$\begin{array}{l}\text { Spirulina } \\
\text { platensis }\end{array}$} & \multirow{5}{*}{$\begin{array}{l}\text { 2-hydroxy } \\
\text { ethylammonium } \\
\text { acetate and } \\
\text { 2-hydroxy } \\
\text { ethylammonium } \\
\text { formate } \\
\text { (1:1) }\end{array}$} & \multirow{5}{*}{ None } & Single IL extraction & \multirow{5}{*}{$\begin{array}{l}\text { Allophycocyanin: } \\
6.34 \mathrm{mg} \mathrm{g}^{-1} \\
\text { Phycocyanin: } \\
5.95 \mathrm{mg} \mathrm{g}^{-1} \\
\text { Phycoerythrin: } \\
2.62 \mathrm{mg} \mathrm{g}^{-1}\end{array}$} & \multirow{5}{*}{ [81] } \\
\hline & & & US bath: $25^{\circ} \mathrm{C}$ and $25 \mathrm{kHz}$ & & \\
\hline & & & $\begin{array}{l}\text { Solvent:Biomass concentration: } \\
\qquad 7.93 \mathrm{~mL} \mathrm{~g}^{-1}\end{array}$ & & \\
\hline & & & $\mathrm{pH}: 6.50$ & & \\
\hline & & & Extraction time: $30 \mathrm{~min}$ & & \\
\hline
\end{tabular}


Table 2. Cont.

\begin{tabular}{|c|c|c|c|c|c|}
\hline $\begin{array}{l}\text { Microalgae } \\
\text { Strain }\end{array}$ & $\begin{array}{l}\text { DES/IL Used } \\
\text { (Molar Ratio) }\end{array}$ & $\begin{array}{l}\text { Salt/Polymer } \\
\text { Used (in Case } \\
\text { of ATPS) }\end{array}$ & $\begin{array}{l}\text { Extraction Method } \\
\text { and Conditions }\end{array}$ & Yield & Reference \\
\hline \multirow{3}{*}{$\begin{array}{l}\text { Haematococcus } \\
\text { pluvialis }\end{array}$} & \multirow{3}{*}{$\begin{array}{l}\text { Trihexyl(tetradecyl) } \\
\text { phosphonium bis- } \\
325 \text { triflamide }\end{array}$} & \multirow{3}{*}{ None } & $\begin{array}{l}\text { Single IL extraction, aided with } \\
\text { microgel particle emulsion } \\
\text { (concentration: } 1 \mathrm{~g} \mathrm{~L}^{-1} \text { ) }\end{array}$ & \multirow{3}{*}{$\begin{array}{l}\text { Protein recovery: } \\
\qquad>90 \%\end{array}$} & \multirow{3}{*}{ [82] } \\
\hline & & & Solvent:Biomass ratio 3:7 & & \\
\hline & & & Mixing time: $120 \mathrm{~min}$ & & \\
\hline \multirow{3}{*}{$\begin{array}{l}\text { Chlorella } \\
\text { vulgaris }\end{array}$} & \multirow{3}{*}{$\begin{array}{l}\text { Cholinium 2- } \\
\text { hydroxy-3-morpho } \\
\text { linopropanesulfonate }\end{array}$} & \multirow{3}{*}{ None } & Single IL extraction & \multirow{3}{*}{$\begin{array}{l}\text { Protein recovery: } \\
\quad 95.0 \pm 1.9 \%\end{array}$} & \multirow{3}{*}{ [83] } \\
\hline & & & $\begin{array}{c}\text { US: } 400 \mathrm{~W} ; 24 \mathrm{kHz} ; 5 \mathrm{~s} \text { on } / 5 \mathrm{~s} \text { off } \\
\text { pulse mode }\end{array}$ & & \\
\hline & & & pH: 7.00 & & \\
\hline \multirow{4}{*}{$\begin{array}{l}\text { Neochloris } \\
\text { oleabundans }\end{array}$} & \multirow{4}{*}{$\begin{array}{l}\text { Tributylmethyl } \\
\text { phosphonium } \\
\text { methyl sulfate } \\
\text { (40\% solution) }\end{array}$} & \multirow{4}{*}{ None } & Single IL extraction & \multirow{4}{*}{$\begin{array}{l}\text { Protein recovery: } \\
80 \%\end{array}$} & \multirow{4}{*}[84]{} \\
\hline & & & $\begin{array}{l}\text { Biomass:Solvent concentration: } \\
6.67 \mathrm{~g} \mathrm{~L}^{-1}\end{array}$ & & \\
\hline & & & Temperature: $45^{\circ} \mathrm{C}$ & & \\
\hline & & & Extraction time: $30 \mathrm{~min}$ & & \\
\hline \multirow{4}{*}{$\begin{array}{l}\text { Neochloris } \\
\text { oleabundans }\end{array}$} & \multirow{4}{*}{$\begin{array}{c}\text { Cholinium } \\
\text { dihydrogen } \\
\text { phosphate }(14 \mathrm{wt} \%)\end{array}$} & \multirow{4}{*}{$\begin{array}{l}\text { Polypropylene } \\
\text { glycol } 440 \\
(40 \mathrm{wt} \%)\end{array}$} & IL-ATPS extraction & \multirow{4}{*}{$\begin{array}{l}\text { Protein recovery: } \\
82 \%\end{array}$} & \multirow{4}{*}{ [86] } \\
\hline & & & $\begin{array}{l}\text { Microalgae suspension: } 2.5 \mathrm{mg} \\
\text { (dry weight) } / \mathrm{mL}\end{array}$ & & \\
\hline & & & Extraction conditions: $50 \mathrm{rpm}, 1 \mathrm{~h}$ & & \\
\hline & & & Room Temperature (RT) & & \\
\hline \multirow{2}{*}{$\begin{array}{l}\text { Isochrysis } \\
\text { galbana }\end{array}$} & \multirow{2}{*}{$\begin{array}{l}\text { 1-decyl-3- } \\
\text { methylimidazolium } \\
\text { chloride }(15 \mathrm{wt} \%)\end{array}$} & \multirow{2}{*}{$\begin{array}{c}\mathrm{K}_{3} \mathrm{PO}_{4} \\
\left(20 w \mathrm{w}^{\mathrm{o}} \mathrm{)}\right)\end{array}$} & $\begin{array}{l}\text { IL-ATPS extraction: } 10,000 \mathrm{rpm}, \\
10 \mathrm{~min}\end{array}$ & \multirow{2}{*}{$\begin{array}{l}\text { Protein separation: } \\
100 \% \text { in the } \\
\text { top phase }\end{array}$} & \multirow[t]{2}{*}{ [87] } \\
\hline & & & Temperature: RT & & \\
\hline \multirow{3}{*}{$\begin{array}{l}\text { Neochloris } \\
\text { oleabundans } \\
\text { and } \\
\text { Tetraselmis } \\
\text { suecica }\end{array}$} & \multirow{3}{*}{ Iolilyte 221PG } & \multirow{3}{*}{$\begin{array}{l}\text { Potassium } \\
\text { citrate }\end{array}$} & $\begin{array}{l}\text { IL-ATPS extraction: } 14,000 \mathrm{rpm} \\
\text { and } 30 \mathrm{~min}\end{array}$ & \multirow{3}{*}{$\begin{array}{l}\text { Protein extraction } \\
\text { efficiencies: } \\
75-85 \% \\
\text { (depending on the } \\
\text { tie lines) }\end{array}$} & \multirow{3}{*}{ [88] } \\
\hline & & & Temperature: RT & & \\
\hline & & & pH: 7.0 & & \\
\hline \multirow{2}{*}{$\begin{array}{l}\text { Scenedesmus } \\
\text { dimorphus } \\
\text { (UTEX 1237) }\end{array}$} & $\begin{array}{l}\text { 1,2-propanediol; } \\
\text { chloine chloride; } \\
\text { water }(1: 1: 1)\end{array}$ & None & $\begin{array}{l}\text { Single DES extraction: } 250 \mathrm{rpm} \\
\text { and } 24 \mathrm{~h} \\
\text { Biomass:Solvent ratio: } 10 \mathrm{~g} \mathrm{~L}^{-1} \\
\text { Temperature: RT } \\
\text { US: } 40 \mathrm{~min} \text { with a frequency of } \\
20 \mathrm{kHz} \text { and a range of } 70 \%\end{array}$ & $\begin{array}{l}\text { Protein recovery } \\
\text { yield: } 27 \%\end{array}$ & [118] \\
\hline & $\begin{array}{c}\text { Octanoic acid and } \\
\text { dodecanoic acid } \\
(1: 1), \text { plus a dilute } \\
(5 \%) \text { aqueous } \\
\text { solution of Jeffamine } \\
\text { D-230 }\end{array}$ & None & $\begin{array}{l}\text { Single DES extraction, conditions } \\
\text { not correctly described in article }\end{array}$ & $\begin{array}{l}\text { Protein extraction } \\
\text { efficiency: } 100 \%\end{array}$ & [119] \\
\hline
\end{tabular}

\subsection{Solvent Recovery Options}

From an industrial point of view, recycling and reusing the solvents is essential to achieve a cost-efficient process [120]. However, it is also vital to obtain the product (proteins) without any impurity of solvent or by-product. Thus far, research has focused on transferring the proteins from the matrix to the biodegradable solvent. However, several issues such as solvent recycling, protein recovery from the biodegradable solvent, 
and potential solvent regeneration are not usually addressed and remain to be solved. Mainly because of the low vapor pressure of the solvents used, the isolation of the proteins from ILs or DESs by vaporization (the most extended method) is complicated, implying protein degradation [100]. New approaches have been attempted, such as the use of resins, ultrafiltration, adsorption [120,121]. Liquid-liquid re-extraction can be an efficient approach to isolate the biocompounds and recover the solvent [122], although organic solvents could be involved, limiting the greenness of the process.

The liquid-liquid re-extraction (or back-extraction) method is preferred for studies concerning protein recovery. Nonetheless, little research has been reported about the recovery problem of these new biodegradable solvents. For example, Zeng et al. used a sodium dodecyl sulfate solution as a stripping reagent to recover the DESs employed in a $\mathrm{K}_{2} \mathrm{HPO}_{4}$-ATPS system (choline chloride-urea, tetramethylammonium chloride-urea, tetrapropylammonium bromide-urea, and choline chloride-methylurea). However, they did not succeed, due to their hydrophilic character [24]. Li et al. managed to back-extract the proteins from a DES-ATPS $\left(\mathrm{K}_{3} \mathrm{PO}_{4}\right.$ and betaine-urea) by forming a new ATPS with fresh $\mathrm{K}_{3} \mathrm{PO}_{4}$ aqueous phase mixed with ethanol (to improve the phase-forming ability of the DES). The ATPS created was shaken mechanically for $12 \mathrm{~min}$, and then the DES phase was collected. Unfortunately, the highest back-extraction efficiency obtained was relatively low (32.66\%) [117]. In turn, Xu et al. studied the extraction efficiency for BSA and trypsin with a DES-ATPS formed by $\mathrm{K}_{2} \mathrm{HPO}_{4}$ and choline chloride-glycerol, obtaining extraction yields of 98.71 and $94.36 \%$, respectively. Then, to obtain the BSA from the DES-rich phase, $1.8 \mathrm{~g}$ of $\mathrm{K}_{2} \mathrm{HPO}_{4}$ were added to $0.27 \mathrm{~mL}$ to the DES-rich top phase, forming a new DES-ATPS, fixing the ion strength by adding 3\% solution of $\mathrm{NaCl}$, they obtain a highest back-extraction yield of 32.96\% [116]. Similarly, Zhang et al. study BSA's extraction and back extraction efficiencies for two DES: tetramethylammonium chlorideurea (TMAC-U) and tetramethylammonium chloride-glycerol-urea ternary (TMAC-G-U). Once the extraction was performed and the DES phase-separated, they carried out the back extraction by adding a solution of $\mathrm{K}_{2} \mathrm{HPO}_{4}\left(0.70 \mathrm{~g} \mathrm{~mL}^{-1}\right)$ to create a new ATPS system. For TMAC-G-U, the back extraction efficiency achieved was $71.88 \%$, while for the TMAC-U, only a modest $21.02 \%$ was reached. Thus, Zhang et al. confirmed that the main handicap for back-extraction was the high interfacial mass transfer resistance between the two phases, as the addition of glycerol reduced the mass transfer resistance. Furthermore, they also checked the extraction capability of the DES used, showing that it still can be used for further experiments (97.99\% of extraction efficiency for new BSA added) [113].

Regarding ILs, there is even less investigation. The research discussed in Section 4.1 from Rodrigues et al. studied the recovery of the IL by using a precipitating agent (ammonium sulfate), concluding that it could be reused up to three times, although the extraction capabilities were reduced [81]. Alternatively, Orr et al. studied the recycling of the IL employed for selective lipid extraction through anti-solvent precipitation, adding methanol to the biomass-IL mixture. Then, the precipitated IL was separated from the biomass by centrifugation, and finally, the methanol was eliminated via evaporation. Although chlorophyll was also recovered along with the IL, they obtained an average recovery of $98.0 \%$, showing a similar performance in further extraction cycles. Thus, more studies focusing on the recovery of other impurities should be performed [123].

Furthermore, in the context of a biorefinery, these solvent recovery processes have not been put into effect at an industrial level, although given the low toxicity of NADESs, they might not need to be recovered, which would diminish the overall cost of the process [124] Therefore, despite the bright present and future of biodegradable solvents, there is an urgent need to develop green, reliable, and straightforward methods that will enable us to recover and purify the proteins and that allows correct recycling and regeneration of the solvent used so that the environmental impact is minimized or negligible. The current state of the art is in its infancy, and there are very few studies dealing with protein purification or solvent recovery issues. 


\section{Conclusions and Future Perspectives}

To solve the upcoming protein shortage, new alternatives to animal protein must appear, reducing the environmental consequences of current protein production processes. Microalgae biorefinery is a bright answer to this problem because it is an excellent protein source (around half of the microalgae dry weight is protein, containing all nine essential amino acids). At the same time, these microorganisms can reduce atmospheric $\mathrm{CO}_{2}$. However, the recovery of proteins from the microalgae matrix is complicated, and it is usually considered the bottleneck of the process. For protein recovery, multiple available techniques allow protein obtaining, and depending on their fundamentals, different purity levels will be attained. All the techniques discussed in this review have different advantages, but they also present some drawbacks. For example, despite precipitation being a straightforward approach, still low yields are obtained, while chromatography provides high efficiencies, but it is challenging to scale up the process. The solvent extraction method is one of the most employed, yet organic solvents go against the sustainability desirable for the process. In this context, ILs, and especially DESs, have been revealed as a greener alternative for protein extraction due to their excellent physicochemical properties that enable an efficient and environmentally friendly recovery.

There is no doubt that biodegradable solvents will be the key to new green processes for obtaining many bioactive compounds. Nevertheless, more efforts are needed to investigate ILs and DESs limitations, and consequently, the ATPS approach. In particular, from our view, forthcoming studies and developments should focus on: (I) preparing more efficient DESs or NADESs to extract protein from microalgae, as they stand as a more environmentally friendly protein source; (II) recovering the proteins sustainably from the solvent, paying attention to how to reuse the solvents employed in further extraction procedures; (III) fully understanding the nature and behavior of DESs and ATPS systems, in order to obtain more selective solvents for the analyte to be separated. Shedding light on these items would provide incredible advances not only for microalgae protein extraction but also in separation science.

Author Contributions: Conceptualization, S.B., P.A.G.-E. and B.C.-G.; analysis of the information, investigation, and writing of the paper D.M., E.M.R., S.B., P.A.G.-E. and B.C.-G.; writing of the paper, D.M. and E.M.R.; review and editing S.B., P.A.G.-E. and B.C.-G. All authors have read and agreed to the published version of the manuscript.

Funding: This research was funded by MICINN-FEDER (projects PID2020-113544RB-I00 and CTQ2017-84006-C3-1-R). The authors also thank the Regional Government of Castilla y León and the EU-FEDER (CLU 2017-09). Elena M. Rojo would like to thank the "Ministerio de Ciencia, Innovación y Universidades" for her doctorate scholarship (PRE2018-083845). David Moldes would like to thank the "Ministerio de Universidades" for his FPU grant (FPU20/02086).

Institutional Review Board Statement: Not applicable.

Informed Consent Statement: Not applicable.

Data Availability Statement: Not applicable.

Acknowledgments: The authors would also thank Laura García for Figure 1 illustration.

Conflicts of Interest: The authors declare no conflict of interest.

\section{References}

1. Chou, C.J.; Affolter, M.; Kussmann, M. A Nutrigenomics View of Protein Intake. In Progress in Molecular Biology and Translational Science; Elsevier: Amsterdam, The Netherlands, 2012; Volume 108, pp. 51-74.

2. UN Department of Economics and Social Affairs World Population Prospects-Population Division-United Nations. Available online: https://esa.un.org/unpd/wpp/ (accessed on 27 January 2022).

3. Shahid, A.; Malik, S.; Zhu, H.; Xu, J.; Nawaz, M.Z.; Nawaz, S.; Asraful Alam, M.; Mehmood, M.A. Cultivating microalgae in wastewater for biomass production, pollutant removal, and atmospheric carbon mitigation; a review. Sci. Total Environ. 2020, 704, 135303. [CrossRef] [PubMed] 
4. Röös, E.; Bajželj, B.; Smith, P.; Patel, M.; Little, D.; Garnett, T. Protein futures for Western Europe: Potential land use and climate impacts in 2050. Reg. Environ. Chang. 2017, 17,367-377. [CrossRef]

5. Naseri, A.; Marinho, G.S.; Holdt, S.L.; Bartela, J.M.; Jacobsen, C. Enzyme-assisted extraction and characterization of protein from red seaweed Palmaria palmata. Algal Res. 2020, 47, 101849. [CrossRef]

6. Molino, A.; Iovine, A.; Casella, P.; Mehariya, S.; Chianese, S.; Cerbone, A.; Rimauro, J.; Musmarra, D. Microalgae characterization for consolidated and new application in human food, animal feed and nutraceuticals. Int. J. Environ. Res. Public Health 2018, 15, 2436. [CrossRef]

7. Rojo, E.M.; Piedra, I.; González, A.M.; Vega, M.; Bolado, S. Effect of process parameters on the valorization of components from microalgal and microalgal-bacteria biomass by enzymatic hydrolysis. Bioresour. Technol. 2021, 335, 125256. [CrossRef]

8. Venkata Mohan, S.; Hemalatha, M.; Chakraborty, D.; Chatterjee, S.; Ranadheer, P.; Kona, R. Algal biorefinery models with self-sustainable closed loop approach: Trends and prospective for blue-bioeconomy. Bioresour. Technol. 2020, $295,122128$. [CrossRef]

9. Karemore, A.; Sen, R. Downstream processing of microalgal feedstock for lipid and carbohydrate in a biorefinery concept: A holistic approach for biofuel applicationst. RSC Adv. 2016, 6, 29486-29496. [CrossRef]

10. Bhattacharya, M.; Goswami, S. Microalgae-A green multi-product biorefinery for future industrial prospects. Biocatal. Agric. Biotechnol. 2020, 25, 101580. [CrossRef]

11. Gifuni, I.; Pollio, A.; Safi, C.; Marzocchella, A.; Olivieri, G. Current Bottlenecks and Challenges of the Microalgal Biorefinery. Trends Biotechnol. 2019, 37, 242-252. [CrossRef]

12. Shahid, A.; Khan, F.; Ahmad, N.; Farooq, M.; Mehmood, M.A. Microalgal carbohydrates and proteins: Synthesis, extraction, applications, and challenges. In Microalgae Biotechnology for Food, Health and High Value Products; Springer: Singapore, 2020; pp. $433-468$.

13. Dolganyuk, V.; Belova, D.; Babich, O.; Prosekov, A.; Ivanova, S.; Katserov, D.; Patyukov, N.; Sukhikh, S. Microalgae: A promising source of valuable bioproducts. Biomolecules 2020, 10, 1153. [CrossRef]

14. Córdova, O.; Chamy, R. Microalgae to biogas: Microbiological communities involved. In Microalgae Cultivation for Biofuels Production; Academic Press: Cambridge, MA, USA, 2019; pp. 227-249.

15. Nitsos, C.; Filali, R.; Taidi, B.; Lemaire, J. Current and novel approaches to downstream processing of microalgae: A review. Biotechnol. Adv. 2020, 45, 107650. [CrossRef] [PubMed]

16. Corrêa, P.S.; Júnior, W.G.M.; Martins, A.A.; Caetano, N.S.; Mata, T.M. Microalgae Biomolecules: Extraction, Separation and Purification Methods. Processes 2021, 9, 10. [CrossRef]

17. Santana-Mayor, Á.; Rodríguez-Ramos, R.; Herrera-Herrera, A.V.; Socas-Rodríguez, B.; Rodríguez-Delgado, M.Á. Deep eutectic solvents. The new generation of green solvents in analytical chemistry. TrAC Trends Anal. Chem. 2020, 134, 116108. [CrossRef]

18. Chew, K.W.; Yap, J.Y.; Show, P.L.; Suan, N.H.; Juan, J.C.; Ling, T.C.; Lee, D.J.; Chang, J.S. Microalgae biorefinery: High value products perspectives. Bioresour. Technol. 2017, 229, 53-62. [CrossRef]

19. Grossmann, L.; Hinrichs, J.; Weiss, J. Cultivation and downstream processing of microalgae and cyanobacteria to generate protein-based technofunctional food ingredients. Crit. Rev. Food Sci. Nutr. 2020, 60, 2961-2989. [CrossRef]

20. Timira, V.; Meki, K.; Li, Z.; Lin, H.; Xu, M.; Pramod, S.N. A comprehensive review on the application of novel disruption techniques for proteins release from microalgae. Crit. Rev. Food Sci. Nutr. 2021, 1-17. [CrossRef]

21. Papachristou, I.; Akaberi, S.; Silve, A.; Navarro-López, E.; Wüstner, R.; Leber, K.; Nazarova, N.; Müller, G.; Frey, W. Analysis of the lipid extraction performance in a cascade process for Scenedesmus almeriensis biorefinery. Biotechnol. Biofuels 2021, 14, 20. [CrossRef]

22. Eppink, M.H.M.; Ventura, S.P.M.; Coutinho, J.A.P.; Wijffels, R.H. Multiproduct Microalgae Biorefineries Mediated by Ionic Liquids. Trends Biotechnol. 2021, 39, 1131-1143. [CrossRef]

23. Liu, S.; Li, Z.; Yu, B.; Wang, S.; Shen, Y.; Cong, H. Recent advances on protein separation and purification methods. Adv. Colloid Interface Sci. 2020, 284, 102254. [CrossRef]

24. Zeng, Q.; Wang, Y.; Huang, Y.; Ding, X.; Chen, J.; Xu, K. Deep eutectic solvents as novel extraction media for protein partitioning Analyst 2014, 139, 2565-2573. [CrossRef]

25. Zainal-Abidin, M.H.; Hayyan, M.; Hayyan, A.; Jayakumar, N.S. New horizons in the extraction of bioactive compounds using deep eutectic solvents: A review. Anal. Chim. Acta 2017, 979, 1-23. [CrossRef] [PubMed]

26. Meng, J.; Wang, Y.; Zhou, Y.; Chen, J.; Wei, X.; Ni, R.; Liu, Z.; Xu, F. Development of different deep eutectic solvent aqueous biphasic systems for the separation of proteins. RSC Adv. 2019, 9, 14116-14125. [CrossRef]

27. Sequeira, R.A.; Bhatt, J.; Prasad, K. Recent Trends in Processing of Proteins and DNA in Alternative Solvents: A Sustainable Approach. Sustain. Chem. 2020, 1, 116-137. [CrossRef]

28. Amorim, M.L.; Soares, J.; dos Reis Coimbra, J.S.; de Oliveira Leite, M.; Albino, L.F.T.; Martins, M.A. Microalgae proteins: Production, separation, isolation, quantification, and application in food and feed. Crit. Rev. Food Sci. Nutr. 2020, 61, 1976-2002. [CrossRef]

29. Skoog, D.A.; Holler, F.J.; Crouch, S.R. Principles of Instrumental Analysis; Cengage Learning: Boston, MA, USA, 2017.

30. Phan, N.V.H.; Sussitz, H.F.; Ladenhauf, E.; Pum, D.; Lieberzeit, P.A. Combined layer/particle approaches in surface molecular imprinting of proteins: Signal enhancement and competition. Sensors 2018, 18, 180. [CrossRef] 
31. Farzi-Khajeh, H.; Safa, K.D.; Dastmalchi, S. Arsanilic acid modified superparamagnetic iron oxide nanoparticles for Purification of alkaline phosphatase from hen's egg yolk. J. Chromatogr. B 2017, 1061, 26-33. [CrossRef]

32. Zhu, H.-G.; Tang, H.-Q.; Cheng, Y.-Q.; Li, Z.-G.; Tong, L.-T. Electrostatic separation technology for obtaining plant protein concentrates: A review. Trends Food Sci. Technol. 2021, 113, 66-76. [CrossRef]

33. Bertsch, P.; Böcker, L.; Mathys, A.; Fischer, P. Proteins from microalgae for the stabilization of fluid interfaces, emulsions, and foams. Trends Food Sci. Technol. 2021, 108, 326-342. [CrossRef]

34. Böcker, L.; Bertsch, P.; Wenner, D.; Teixeira, S.; Bergfreund, J.; Eder, S.; Fischer, P.; Mathys, A. Effect of Arthrospira platensis microalgae protein purification on emulsification mechanism and efficiency. J. Colloid Interface Sci. 2021, 584, 344-353. [CrossRef]

35. Pereira, A.M.; Lisboa, C.R.; Costa, J.A.V. High protein ingredients of microalgal origin: Obtainment and functional properties. Innov. Food Sci. Emerg. Technol. 2018, 47, 187-194. [CrossRef]

36. Pylaeva, S.; Brehm, M.; Sebastiani, D. Salt bridge in aqueous solution: Strong structural motifs but weak enthalpic effect. Sci. Rep. 2018, 8, 13626. [CrossRef]

37. Barbarino, E.; Lourenço, S.O. An evaluation of methods for extraction and quantification of protein from marine macro-and microalgae. J. Appl. Phycol. 2005, 17, 447-460. [CrossRef]

38. Saxena, A.; Tripathi, B.P.; Kumar, M.; Shahi, V.K. Membrane-based techniques for the separation and purification of proteins: An overview. Adv. Colloid Interface Sci. 2009, 145, 1-22. [CrossRef] [PubMed]

39. Yang, F.; Yang, P. Protein-Based Separation Membranes: State of the Art and Future Trends. Adv. Energy Sustain. Res. 2021, 2, 2100008. [CrossRef]

40. Zeman, L.J.; Zydney, A.L. Microfiltration and Ultrafiltration: Principles and Applications; CRC Press: Boca Raton, FL, USA, 2017.

41. Liu, S.; Gifuni, I.; Mear, H.; Frappart, M.; Couallier, E. Recovery of soluble proteins from Chlorella vulgaris by bead-milling and microfiltration: Impact of the concentration and the physicochemical conditions during the cell disruption on the whole process. Process Biochem. 2021, 108, 34-47. [CrossRef]

42. Zhang, Y.; Fu, Q. Algal fouling of microfiltration and ultrafiltration membranes and control strategies: A review. Sep. Purif. Technol. 2018, 203, 193-208. [CrossRef]

43. Zhang, Z.; Li, L. Efficient synthesis of molecularly imprinted polymers with bio-recognition sites for the selective separation of bovine hemoglobin. J. Sep. Sci. 2018, 41, 2479-2487. [CrossRef]

44. Md Saleh, N.I.; Wan Ab Karim Ghani, W.A.; Mustapa Kamal, S.M.; Harun, R. Performance of Single and Two-Stage Cross-Flow Ultrafiltration Membrane in Fractionation of Peptide from Microalgae Protein Hydrolysate (Nannochloropsis gaditana). Processes 2021, 9, 610. [CrossRef]

45. Balti, R.; Zayoud, N.; Hubert, F.; Beaulieu, L.; Massé, A. Fractionation of Arthrospira platensis (Spirulina) water soluble proteins by membrane diafiltration. Sep. Purif. Technol. 2021, 256, 117756. [CrossRef]

46. Vidya, B.; Palaniswamy, M.; Angayarkanni, J.; Nawaz, K.A.; Thandeeswaran, M.; Chaithanya, K.K.; Tekluu, B.; Muthusamy, K.; Gopalakrishnan, V.K. Purification and characterization of $\beta$-galactosidase from newly isolated Aspergillus terreus (KUBCF1306) and evaluating its efficacy on breast cancer cell line (MCF-7). Bioorg. Chem. 2020, 94, 103442. [CrossRef]

47. Ta, H.Y.; Collin, F.; Perquis, L.; Poinsot, V.; Ong-Meang, V.; Couderc, F. Twenty years of amino acid determination using capillary electrophoresis: A review. Anal. Chim. Acta 2021, 1174, 338233. [CrossRef] [PubMed]

48. Lundanes, E.; Reubsaet, L.; Greibrokk, T. Chromatography: Basic Principles, Sample Preparations and Related Methods; John Wiley \& Sons: Hoboken, NJ, USA, 2013.

49. Wang, A.; Islam, M.N.; Qin, X.; Wang, H.; Peng, Y.; Ma, C. Purification, identification, and characterization of d-galactose-6sulfurylase from marine algae (Betaphycus gelatinus). Carbohydr. Res. 2014, 388, 94-99. [CrossRef] [PubMed]

50. Tang, Z.; Zhao, J.; Ju, B.; Li, W.; Wen, S.; Pu, Y.; Qin, S. One-step chromatographic procedure for purification of B-phycoerythrin from Porphyridium cruentum. Protein Expr. Purif. 2016, 123, 70-74. [CrossRef]

51. Staby, A.; Rathore, A.S.; Ahuja, S. Preparative Chromatography for Separation of Proteins; John Wiley \& Sons: Hoboken, NJ, USA, 2017.

52. Przybycien, T.M.; Pujar, N.S.; Steele, L.M. Alternative bioseparation operations: Life beyond packed-bed chromatography. Curr. Opin. Biotechnol. 2004, 15, 469-478. [CrossRef]

53. Kress, C.; Sadowski, G.; Brandenbusch, C. Solubilization of proteins in aqueous two-phase extraction through combinations of phase-formers and displacement agents. Eur. J. Pharm. Biopharm. 2017, 112, 38-44. [CrossRef] [PubMed]

54. Rice, N.M.; Irving, H.; Leonard, M.A. Nomenclature for liquid-liquid distribution (solvent extraction) (IUPAC Recommendations 1993). Pure Appl. Chem. 1993, 65, 2373-2396. [CrossRef]

55. Kumar, M.; Tomar, M.; Potkule, J.; Verma, R.; Punia, S.; Mahapatra, A.; Belwal, T.; Dahuja, A.; Joshi, S.; Berwal, M.K.; et al. Advances in the plant protein extraction: Mechanism and recommendations. Food Hydrocoll. 2021, 106595. [CrossRef]

56. Chemat, F.; Abert Vian, M.; Ravi, H.K.; Khadhraoui, B.; Hilali, S.; Perino, S.; Fabiano Tixier, A.-S. Review of alternative solvents for green extraction of food and natural products: Panorama, principles, applications and prospects. Molecules 2019, $24,3007$. [CrossRef]

57. Cravotto, G.; Boffa, L.; Mantegna, S.; Perego, P.; Avogadro, M.; Cintas, P. Improved extraction of vegetable oils under high-intensity ultrasound and/or microwaves. Ultrason. Sonochem. 2008, 15, 898-902. [CrossRef]

58. Chemat, F.; Vian, M.A.; Cravotto, G. Green extraction of natural products: Concept and principles. Int. J. Mol. Sci. 2012, 13, 8615-8627. [CrossRef] 
59. Phong, W.N.; Show, P.L.; Teh, W.H.; Teh, T.X.; Lim, H.M.Y.; binti Nazri, N.S.; Tan, C.H.; Chang, J.-S.; Ling, T.C. Proteins recovery from wet microalgae using liquid biphasic flotation (LBF). Bioresour. Technol. 2017, 244, 1329-1336. [CrossRef]

60. Clarke, C.J.; Tu, W.-C.; Levers, O.; Brohl, A.; Hallett, J.P. Green and sustainable solvents in chemical processes. Chem. Rev. 2018, 118, 747-800. [CrossRef] [PubMed]

61. Chen, Y.; Mu, T. Revisiting greenness of ionic liquids and deep eutectic solvents. Green Chem. Eng. 2021, 2, 174-186. [CrossRef]

62. Bubalo, M.C.; Vidović, S.; Redovniković, I.R.; Jokić, S. New perspective in extraction of plant biologically active compounds by green solvents. Food Bioprod. Process. 2018, 109, 52-73. [CrossRef]

63. Chowdhury, S.; Rakshit, A.; Acharjee, A.; Saha, B. Biodegradability and biocompatibility: Advancements in synthetic surfactants. J. Mol. Liq. 2021, 324, 115105. [CrossRef]

64. Brown, D.M.; Lyon, D.; Saunders, D.M.V.; Hughes, C.B.; Wheeler, J.R.; Shen, H.; Whale, G. Biodegradability assessment of complex, hydrophobic substances: Insights from gas-to-liquid (GTL) fuel and solvent testing. Sci. Total Environ. 2020, 727, 138528. [CrossRef]

65. Asenjo, J.A.; Andrews, B.A. Aqueous two-phase systems for protein separation: Phase separation and applications. J. Chromatogr. A 2012, 1238, 1-10. [CrossRef]

66. Hatti-Kaul, R. Aqueous Two-Phase Systems: Methods and Protocols; Springer Science \& Business Media: Berlin, Germany, 2000; Volume 11.

67. Pereira, J.F.B.; Freire, M.G.; Coutinho, J.A.P. Aqueous two-phase systems: Towards novel and more disruptive applications. Fluid Phase Equilib. 2020, 505, 112341. [CrossRef]

68. Xie, Y.; Xing, H.; Yang, Q.; Bao, Z.; Su, B.; Ren, Q. Aqueous Biphasic System Containing Long Chain Anion-Functionalized Ionic Liquids for High-Performance Extraction. ACS Sustain. Chem. Eng. 2015, 3, 3365-3372. [CrossRef]

69. Schuur, B.; Brouwer, T.; Smink, D.; Sprakel, L.M.J. Green solvents for sustainable separation processes. Curr. Opin. Green Sustain. Chem. 2019, 18, 57-65. [CrossRef]

70. Baskaran, D.; Chinnappan, K.; Manivasagan, R.; Mahadevan, D.K. Partitioning of crude protein from aqua waste using PEG 600-inorganic salt Aqueous Two-Phase Systems. Chem. Data Collect. 2018, 15, 143-152. [CrossRef]

71. Chen, X.; Liu, J.; Wang, J. Ionic liquids in the assay of proteins. Anal. Methods 2010, 2, 1222-1226. [CrossRef]

72. Benvenutti, L.; Zielinski, A.A.F.; Ferreira, S.R.S. Which is the best food emerging solvent: IL, DES or NADES? Trends Food Sci. Technol. 2019, 90, 133-146. [CrossRef]

73. Choi, Y.H.; Verpoorte, R. Green solvents for the extraction of bioactive compounds from natural products using ionic liquids and deep eutectic solvents. Curr. Opin. Food Sci. 2019, 26, 87-93. [CrossRef]

74. Seddon, K.R. Ionic liquids for clean technology. J. Chem. Technol. Biotechnol. 1997, 68, 351-356. [CrossRef]

75. Cvjetko Bubalo, M.; Vidović, S.; Radojčić Redovniković, I.; Jokić, S. Green solvents for green technologies. J. Chem. Technol. Biotechnol. 2015, 90, 1631-1639. [CrossRef]

76. Passos, H.; Freire, M.G.; Coutinho, J.A.P. Ionic liquid solutions as extractive solvents for value-added compounds from biomass. Green Chem. 2014, 16, 4786-4815. [CrossRef]

77. Nasirpour, N.; Mohammadpourfard, M.; Zeinali Heris, S. Ionic liquids: Promising compounds for sustainable chemical processes and applications. Chem. Eng. Res. Des. 2020, 160, 264-300. [CrossRef]

78. Bubalo, M.C.; Radošević, K.; Redovniković, I.R.; Halambek, J.; Srček, V.G. A brief overview of the potential environmental hazards of ionic liquids. Ecotoxicol. Environ. Saf. 2014, 99, 1-12. [CrossRef]

79. Patel, R.; Kumari, M.; Khan, A.B. Recent advances in the applications of ionic liquids in protein stability and activity: A review. Appl. Biochem. Biotechnol. 2014, 172, 3701-3720. [CrossRef]

80. Xiao, J.; Chen, G.; Li, N. Ionic liquid solutions as a green tool for the extraction and isolation of natural products. Molecules 2018, 23, 1765. [CrossRef] [PubMed]

81. Rodrigues, R.D.P.; de Castro, F.C.; de Santiago-Aguiar, R.S.; Rocha, M.V.P. Ultrasound-assisted extraction of phycobiliproteins from Spirulina (Arthrospira) platensis using protic ionic liquids as solvent. Algal Res. 2018, 31, 454-462. [CrossRef]

82. Desai, R.K.; Monteillet, H.; Li, X.; Schuur, B.; Kleijn, J.M.; Leermakers, F.A.M.; Wijffels, R.H.; Eppink, M.H.M. One-step mild biorefinery of functional biomolecules from microalgae extracts. React. Chem. Eng. 2018, 3, 182-187. [CrossRef]

83. Lee, S.Y.; Show, P.L.; Ling, T.C.; Chang, J.-S. Single-step disruption and protein recovery from Chlorella vulgaris using ultrasonication and ionic liquid buffer aqueous solutions as extractive solvents. Biochem. Eng. J. 2017, 124, 26-35. [CrossRef]

84. Desai, R.K.; Fernandez, M.S.; Wijffels, R.H.; Eppink, M.H.M. Mild fractionation of hydrophilic and hydrophobic components from Neochloris oleoabundans using ionic liquids. Front. Bioeng. Biotechnol. 2019, 7, 284. [CrossRef]

85. Zeng, Q.; Wang, Y.; Li, N.; Huang, X.; Ding, X.; Lin, X.; Huang, S.; Liu, X. Extraction of proteins with ionic liquid aqueous two-phase system based on guanidine ionic liquid. Talanta 2013, 116, 409-416. [CrossRef]

86. Suarez Ruiz, C.A.; Kwaijtaal, J.; Peinado, O.C.; Van Den Berg, C.; Wijffels, R.H.; Eppink, M.H.M. Multistep Fractionation of Microalgal Biomolecules Using Selective Aqueous Two-Phase Systems. ACS Sustain. Chem. Eng. 2020, 8, 2441-2452. [CrossRef]

87. Santos, J.H.P.M.; Trigo, J.P.; Maricato, E.; Nunes, C.; Coimbra, M.A.; Ventura, S.P.M. Fractionation of isochrysis galbana proteins, arabinans, and glucans using ionic-liquid-based aqueous biphasic systems. ACS Sustain. Chem. Eng. 2018, 6, 14042-14053. [CrossRef] 
88. Suarez Garcia, E.; Suarez Ruiz, C.A.; Tilaye, T.; Eppink, M.H.M.; Wijffels, R.H.; van den Berg, C. Fractionation of proteins and carbohydrates from crude microalgae extracts using an ionic liquid based-aqueous two phase system. Sep. Purif. Technol. 2018, 204, 56-65. [CrossRef]

89. Durand, E.; Lecomte, J.; Villeneuve, P. Are emerging deep eutectic solvents (DES) relevant for lipase-catalyzed lipophilizations? OCL 2015, 22, D408. [CrossRef]

90. Zhao, W.; Chi, X.; Li, H.; He, J.; Long, J.; Xu, Y.; Yang, S. Eco-friendly acetylcholine-carboxylate bio-ionic liquids for controllable $\mathrm{N}$-methylation and N-formylation using ambient $\mathrm{CO}_{2}$ at low temperatures. Green Chem. 2019, 21, 567-577. [CrossRef]

91. Pham, T.P.T.; Cho, C.-W.; Yun, Y.-S. Environmental fate and toxicity of ionic liquids: A review. Water Res. 2010, 44, 352-372. [CrossRef] [PubMed]

92. Petkovic, M.; Seddon, K.R.; Rebelo, L.P.N.; Pereira, C.S. Ionic liquids: A pathway to environmental acceptability. Chem. Soc. Rev. 2011, 40, 1383-1403. [CrossRef] [PubMed]

93. Francisco, M.; van den Bruinhorst, A.; Kroon, M.C. New natural and renewable low transition temperature mixtures (LTTMs): Screening as solvents for lignocellulosic biomass processing. Green Chem. 2012, 14, 2153-2157. [CrossRef]

94. Ratti, R. Ionic liquids: Synthesis and applications in catalysis. Adv. Chem. 2014, 2014, 729842. [CrossRef]

95. Abbott, A.P.; Capper, G.; Davies, D.L.; Rasheed, R.K.; Tambyrajah, V. Novel solvent properties of choline chloride/urea mixtures Chem. Commun. 2003, 70-71. [CrossRef] [PubMed]

96. Martins, M.A.R.; Pinho, S.P.; Coutinho, J.A.P. Insights into the nature of eutectic and deep eutectic mixtures. J. Solution Chem. 2019, 48, 962-982. [CrossRef]

97. Tang, S.; Baker, G.A.; Zhao, H. Ether- and alcohol-functionalized task-specific ionic liquids: Attractive properties and applications Chem. Soc. Rev. 2012, 41, 4030-4066. [CrossRef]

98. Zhang, Q.; Vigier, K.D.O.; Royer, S.; Jerome, F. Deep eutectic solvents: Syntheses, properties and applications. Chem. Soc. Rev. 2012, 41, 7108-7146. [CrossRef]

99. Abbott, A.P.; Boothby, D.; Capper, G.; Davies, D.L.; Rasheed, R.K. Deep eutectic solvents formed between choline chloride and carboxylic acids: Versatile alternatives to ionic liquids. J. Am. Chem. Soc. 2004, 126, 9142-9147. [CrossRef]

100. Huang, J.; Guo, X.; Xu, T.; Fan, L.; Zhou, X.; Wu, S. Ionic deep eutectic solvents for the extraction and separation of natural products. J. Chromatogr. A 2019, 1598, 1-19. [CrossRef] [PubMed]

101. Beyersdorff, T.; Schubert, T.J.S.; Welz-Biermann, U.; Pitner, W.; Abbott, A.P.; McKenzie, K.J.; Ryder, S. Chapter 2: Synthesis of Ionic Liquids. In Electrodeposition from Ionic Liquids; Wiley: Weinheim, Germany, 2017; pp. 17-53.

102. Smith, E.L.; Abbott, A.P.; Ryder, K.S. Deep eutectic solvents (DESs) and their applications. Chem. Rev. 2014, 114, 11060-11082. [CrossRef] [PubMed]

103. Abranches, D.O.; Martins, M.A.R.; Silva, L.P.; Schaeffer, N.; Pinho, S.P.; Coutinho, J.A.P. Phenolic hydrogen bond donors in the formation of non-ionic deep eutectic solvents: The quest for type v des. Chem. Commun. 2019, 55, 10253-10256. [CrossRef] [PubMed]

104. Hansen, B.B.; Spittle, S.; Chen, B.; Poe, D.; Zhang, Y.; Klein, J.M.; Horton, A.; Adhikari, L.; Zelovich, T.; Doherty, B.W.; et al. Deep eutectic solvents: A review of fundamentals and applications. Chem. Rev. 2020, 121, 1232-1285. [CrossRef] [PubMed]

105. Özel, N.; Elibol, M. A review on the potential uses of deep eutectic solvents in chitin and chitosan related processes. Carbohydr. Polym. 2021, 262, 117942. [CrossRef] [PubMed]

106. Farooq, M.Q.; Abbasi, N.M.; Anderson, J.L. Deep eutectic solvents in separations: Methods of preparation, polarity, and applications in extractions and capillary electrochromatography. J. Chromatogr. A 2020, 1633, 461613. [CrossRef]

107. Zhao, B.-Y.; Xu, P.; Yang, F.-X.; Wu, H.; Zong, M.-H.; Lou, W.-Y. Biocompatible deep eutectic solvents based on choline chloride: Characterization and application to the extraction of rutin from Sophora japonica. ACS Sustain. Chem. Eng. 2015, 3, $2746-2755$. [CrossRef]

108. Florindo, C.; Lima, F.; Ribeiro, B.D.; Marrucho, I.M. Deep eutectic solvents: Overcoming 21st century challenges. Curr. Opin. Green Sustain. Chem. 2019, 18, 31-36. [CrossRef]

109. Choi, Y.H.; van Spronsen, J.; Dai, Y.; Verberne, M.; Hollmann, F.; Arends, I.W.C.E.; Witkamp, G.-J.; Verpoorte, R. Are natural deep eutectic solvents the missing link in understanding cellular metabolism and physiology? Plant Physiol. 2011, 156, 1701-1705. [CrossRef]

110. Huang, Y.; Feng, F.; Jiang, J.; Qiao, Y.; Wu, T.; Voglmeir, J.; Chen, Z.-G. Green and efficient extraction of rutin from tartary buckwheat hull by using natural deep eutectic solvents. Food Chem. 2017, 221, 1400-1405. [CrossRef]

111. Mehariya, S.; Fratini, F.; Lavecchia, R.; Zuorro, A. Green extraction of value-added compounds form microalgae: A short review on natural deep eutectic solvents (NaDES) and related pre-treatments. J. Environ. Chem. Eng. 2021, 9, 105989. [CrossRef]

112. Dai, Y.; van Spronsen, J.; Witkamp, G.-J.; Verpoorte, R.; Choi, Y.H. Natural deep eutectic solvents as new potential media for green technology. Anal. Chim. Acta 2013, 766, 61-68. [CrossRef]

113. Zhang, H.; Wang, Y.; Xu, K.; Li, N.; Wen, Q.; Yang, Q.; Zhou, Y. Ternary and binary deep eutectic solvents as a novel extraction medium for protein partitioning. Anal. Methods 2016, 8, 8196-8207. [CrossRef]

114. Grudniewska, A.; de Melo, E.M.; Chan, A.; Gniłka, R.; Boratynski, F.; Matharu, A.S. Enhanced protein extraction from oilseed cakes using glycerol-choline chloride deep eutectic solvents: A biorefinery approach. ACS Sustain. Chem. Eng. 2018, 6, 15791-15800. [CrossRef] 
115. Bai, C.; Wei, Q.; Ren, X. Selective extraction of collagen peptides with high purity from cod skins by deep eutectic solvents. ACS Sustain. Chem. Eng. 2017, 5, 7220-7227. [CrossRef]

116. Xu, K.; Wang, Y.; Huang, Y.; Li, N.; Wen, Q. A green deep eutectic solvent-based aqueous two-phase system for protein extracting Anal. Chim. Acta 2015, 864, 9-20. [CrossRef] [PubMed]

117. Li, N.; Wang, Y.; Xu, K.; Huang, Y.; Wen, Q.; Ding, X. Development of green betaine-based deep eutectic solvent aqueous two-phase system for the extraction of protein. Talanta 2016, 152, 23-32. [CrossRef] [PubMed]

118. Cicci, A.; Sed, G.; Bravi, M. Potential of choline chloride-based natural deep eutectic solvents (NaDES) in the extraction of microalgal metabolites. Chem. Eng. Trans. 2017, 57, 61-66.

119. Sed, G.; Cicci, A.; Jessop, P.G.; Bravi, M. A novel switchable-hydrophilicity, natural deep eutectic solvent (NaDES)-based system for bio-safe biorefinery. RSC Adv. 2018, 8, 37092-37097. [CrossRef]

120. Lee, S.Y.; Khoiroh, I.; Ling, T.C.; Show, P.L. Enhanced recovery of lipase derived from Burkholderia cepacia from fermentation broth using recyclable ionic liquid/polymer-based aqueous two-phase systems. Sep. Purif. Technol. 2017, 179, 152-160. [CrossRef]

121. Dai, Y.; Van Spronsen, J.; Witkamp, G.J.; Verpoorte, R.; Choi, Y.H. Ionic liquids and deep eutectic solvents in natural products research: Mixtures of solids as extraction solvents. J. Nat. Prod. 2013, 76, 2162-2173. [CrossRef] [PubMed]

122. Cláudio, A.F.M.; Ferreira, A.M.; Freire, M.G.; Coutinho, J.A.P. Enhanced extraction of caffeine from guarana seeds using aqueous solutions of ionic liquids. Green Chem. 2013, 15, 2002-2010. [CrossRef]

123. Orr, V.C.A.; Plechkova, N.V.; Seddon, K.R.; Rehmann, L. Disruption and wet extraction of the microalgae Chlorella vulgaris using room-temperature ionic liquids. ACS Sustain. Chem. Eng. 2016, 4, 591-600. [CrossRef]

124. Gullón, P.; Gullón, B.; Romaní, A.; Rocchetti, G.; Lorenzo, J.M. Smart advanced solvents for bioactive compounds recovery from agri-food by-products: A review. Trends Food Sci. Technol. 2020, 101, 182-197. [CrossRef] 